\title{
Chapter 8 \\ Ukrainians in the Czech Republic: \\ On the Pathway from Temporary Foreign \\ Workers to One of the Largest Minority \\ Groups
}

\author{
Yana Leontiyeva
}

\subsection{Introduction}

Ukrainian migration to Czech lands has a long history due to the geographical, cultural and historical closeness of the two countries. As early as the sixteenth century, labour migrants from Halych and Bukovyna used to move for seasonal work, mostly to Bohemia and Moravia (Zilynskyj 1995). At the turn of the nineteenth century, Ukrainian intellectuals who had abandoned their native country for political reasons were drawn primarily to Prague and other big cities within the Austrian part of the Habsburg Empire. During the first decades of the twentieth century, the Ukrainian diaspora, represented by a number of associations with different aims and scopes, was very active educationally (its academic activities included publishing a number of textbooks, dictionaries and encyclopaedias, and establishing a university and the Higher Pedagogical Institute). The subsequent Nazi and Soviet occupations of Czechoslovakia led to the enforced closing down of Ukrainian associations, and most Ukrainian immigrants were assimilated into the majority population (Zilynskyj and Kočík 2001). Many Ukrainians in the Transcarpathian region, which has an especially long and intensive history of migration not only as a borderland region but also as a former part of Czechoslovakia, continued to have a close connection to the Czech lands in many cases based on wider family ties. After the fall of the Soviet Union, the Czech lands experienced an extensive new wave of predominantly economic migrants from Ukraine. The "older" generation of immigrants continue with a more traditional form of civic activity and - at the turn of the century - tended to distance themselves from "new economic" immigrants (Leontiyeva 2005). Over the last decade these new immigrants have become more settled, participating more in

The original version of this chapter was revised. An erratum to this chapter can be found at DOI 10.1007/978-3-319-41776-9_14

Y. Leontiyeva $(\triangle)$

Institute of Sociology, Academy of Sciences of the Czech Republic, Prague, Czech Republic

e-mail: yana.leontiyeva@soc.cas.cz 
civic activity, and there has also been a gradual change in the activities of traditional Ukrainian NGOs aimed at the new wave of immigrants.

Today Ukrainians represent the largest migrant group in the Czech Republic. Researchers are therefore particularly interested in this group, which combines two rather different features when compared with the other two largest groups of migrants: (a) at first glance it is often not recognizable because its members appear culturally not so different from the local population, mostly have decent language skills, keep close contacts with a majority population, and are well integrated into Czech society (unlike the first generation of Vietnamese, who constitute the thirdlargest migrant group); however (b) it is still not that hard to find as it has a large number of members who are often concentrated in certain "migrant jobs" (unlike Slovaks, who can be found in all sectors).

Most of the literature on Ukrainian migration to the Czech Republic is devoted to contemporary labour migration. However, there are a good number of descriptive studies devoted to the history of Ukrainian migration to the Czech lands and the activities of the Ukrainian diaspora, mainly at the end of the nineteenth century and the first half of the twentieth century (Markus 1994; Zilynskyj 1995, 2000; Zilynskyj and Kočík 2001). There are a number of more general studies describing harsh working conditions and the position of Ukrainian immigrants in the labour market (Horáková and Drbohlav 1998; Lupták and Drbohlav 1999; Drbohlav and Dzúrová 2007; Drbohlav et al. 2001); barriers to labour market integration (EzzeddineLukšíková et al. 2006); over-education of Ukrainian migrants (Leontiyeva 2014; Leontiyeva and Pokorná 2014); and other important aspects of social integration and potential settlement (Leontiyeva and Nečasová 2009; Bernard and Mikešová 2014). Some publications focus on more specific topics, such as the quasi-legal system of middlemen intermediating the employment of Ukrainian immigrants (Nekorjak 2006; Čermáková and Nekorjak 2009); irregular Ukrainian immigration (Nekorjak 2007); and less explored areas like transnational motherhood (Ezzeddine 2012), civic participation and community activities (Zilynskyj 2002; Leontiyeva 2005), transformation of national identities of Ukrainian immigrants (Trlifajová 2009), and remittances sent by Ukrainians from the Czech Republic (Leontiyeva and Tollarová 2011; Strielkowski et al. 2012; Leontiyeva 2015). Shared history means that a great deal of attention (especially in ethnological research) has been paid to immigration from Transcarpathian Ukraine, which used to be a part of Czechoslovakia (Uherek and Plochová 2003; Uherek et al. 2008), and also to the resettlement of ethnic Czechs from Ukraine (Valášková et al. 1997; Nosková 1999; Janská and Drbohlav 2001).

\subsection{Today's Ukrainian Migration in Numbers}

The number of Ukrainians in the Czech Republic has grown rapidly in the last 20 years. From less than 10,000 in the early 1990s, the official number of Ukrainian citizens who reside in the Czech Republic today has risen to over 100,000. 
Ukrainians are the largest migrant community in the country: they constitute about $25 \%$ of all migrants and about $40 \%$ of immigrants from countries outside the European Union. The total number of Ukrainian citizens registered by the end of 2015 was 106,019 (MoI 2015a), a significant reduction since the end of 2008, when the number of Ukrainians residing in the country was about 132,000 (CZSO 2015).

In addition to the official numbers, it is worth looking at irregular migration of Ukrainians. According to official statistics, the annual number of Ukrainian citizens who cross the border without valid documents is very small. ${ }^{1}$ However, most researchers and experts agree that Ukrainians (as well as many other immigrant groups) "fell into illegality" in the Czech Republic (Drbohlav and Lachmanová 2008; Leontiyeva and Nečasová 2009), mostly as a result of a rigid migration policy, especially with regard to the extension of work and residence permits. According to the annual Ministry of the Interior report (MoI 2015b), checks in the Czech Republic during 2014 found 1020 Ukrainian citizens without valid documents. At the same time, the official figures in the report suggest that undocumented migration is nowadays considerably lower than it used to be before the country joined the Schengen Area. This may be all the more true in times of economic recession, as the Czech state has imposed more restrictions on employment of third-country nationals. According to estimates, the number of irregular immigrants in the Czech Republic could be as high as the number of officially registered immigrants (Drbohlav et al. 2010), with estimates ranging between 50,000 and 150,000 people (Nekorjak 2007).

Ukrainian migration to the Czech Republic, as is often the case in other migrant groups, is quite "young". The average age of Ukrainian migrants is just under 35 (CZSO 2015). Almost nine in ten (85\%) Ukrainian nationals residing in the Czech Republic are of productive age (between 15 and 59 years of age), while the share of older Ukrainian migrants (60 and above) is negligible (less than 5\%) and more than one in ten (11\%) migrants officially registered in the country are under 15 (CZSO 2015). Despite this significant number of Ukrainian children (who even predominate in several age groups) second-generation Ukrainian migrants do not figure in public and academic discourse, unlike, for example, Vietnamese migrants. This is probably the result of the assimilation of Ukrainian children, who seem to have become an "invisible" part of society in general.

Since the 1990s the share of women among Ukrainian migrants has fluctuated around $40 \%$, with a slight increase during the last 4 years. In 2015 the share of women among Ukrainian migrants was almost 47\% (MoI 2015a). Stagnation of the immigrant inflow due to a change in the approach to newcomers (as discussed below) has resulted in a significant increase in the share of "settled migrants". The share of permanent residence permit holders among Ukrainians in 2000 was less than one-fifth; it was almost one-third in 2008 and more than two-thirds (73\%) by the end of 2015. As in some other EU countries, Ukrainian female migration is more settled (see Chapter 710 on Italy in this volume); the share of permanent residence

\footnotetext{
${ }^{1}$ The Ministry of the Interior reports that in 2014 only 15 Ukrainian citizens were caught crossing the border without valid documents (MoI 2015b).
} 
permit holders is significantly higher among female migrants (76\% compared with $71 \%$ among men) (MoI 2015a).

Comparison of the data from four surveys conducted between 2001 and 2013 suggests that almost half of Ukrainians (between $42 \%$ and $48 \%$ ) in waged employment are married, and a considerable proportion (between 14\% and 16\%) are divorced (Bernard and Leontiyeva 2013). ${ }^{2}$ Transnational families are widespread among Ukrainian migrants in the Czech Republic; in most cases migrants' family members have remained in Ukraine but in some cases migrants' partners are working in other EU countries. A survey conducted in 2010 suggests that economically active Ukrainian men are more often separated from their partners and spouses (compared to female migrants) and that almost half of Ukrainians with children had to leave their offspring in the home country (Leontiyeva and Tollarová 2011).

\subsection{The Predominantly Economic Nature of Ukrainian Migration}

For more than two decades, Ukrainian migration to the Czech Republic has been predominantly economic in nature (similarly to Poland; see Chap. 7), although nowadays the share of family reunions is also growing significantly. Like third-country nationals in general in the EU, most Ukrainian immigrants are employed in the secondary labour market. By the end of 2011, official records reported 68,650 economically active citizens from Ukraine, of whom almost half were self-employed with the other half employed under a regular contract (CZSO 2015). This is the most recent date for which data on the employment of immigrants in the Czech Republic are available. The nature of the economic activities of Ukrainian migrants has obviously changed in recent years. Unfortunately due to changes at the Czech Ministry of Labour and Social Affairs (MoLSA), including restructuring and problems with the implementation of new computer systems for migrant registration, detailed official statistics for Ukrainian citizens employed since 2012 are unavailable. Expert estimates provided by MoLSA since that date are mostly aggregated to include data on all third-country nationals (these estimates are discussed below). Despite the lack of recent data, some recession-related trends are obvious even between 2008 and 2011. Figure 8.1 illustrates the significant decline in the number of directly employed Ukrainians (i.e. those with the status of a regular employee); this group showed an almost 60\% decrease in 2011 compared with 2008. This did not, however, coincide with the mass return of migrants, as the total number of Ukrainians officially registered in the country declined by only $10 \%$ during this period.

\footnotetext{
${ }^{2}$ In spite of obvious methodological shortcomings, available quantitative data produce fairly stable outcomes when it comes to the main characteristics of Ukrainian nationals in waged employment (see Bernard and Leontiyeva 2013).
} 


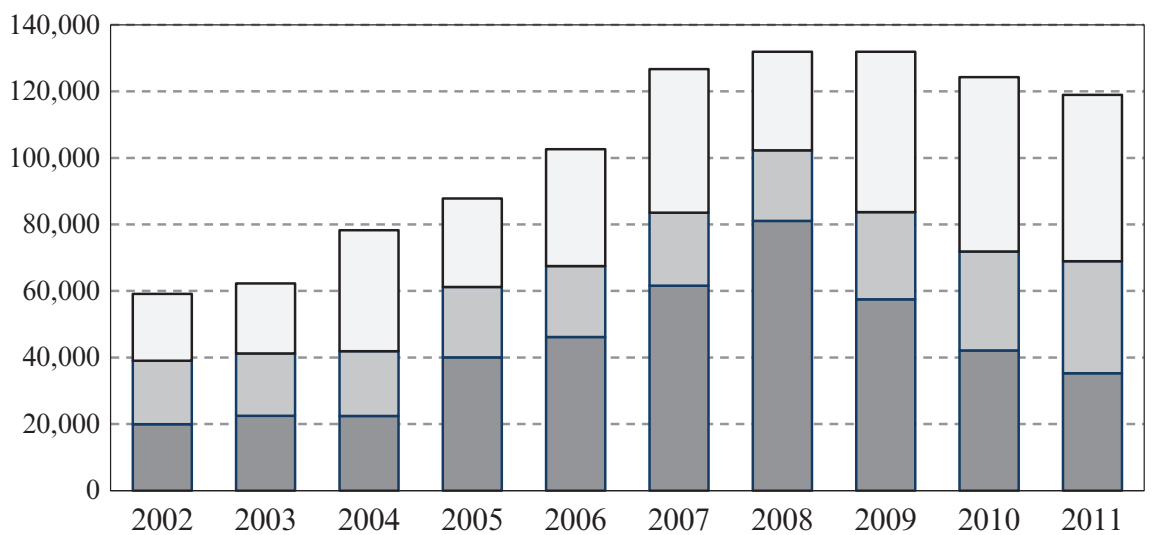

$\square$ regular employees $\square$ self-employed $\square$ other migrants with valid residence permit

Fig. 8.1 Registered economic activities of Ukrainian nationals (Source: CZSO (2015). Foreigners in the Czech Republic 2014)

In order to explain this development a short excursus into recent policy changes towards labour migrants in the Czech Republic is needed. It is important to note that in 2008 the vast majority (91\%) of employed Ukrainians did not have free access to the labour market and had to apply for work permits, which were mostly issued for a period of up to 1 year and assigned to a specific employer, job and region (see Chap. 7 for comparison with the Polish case on facilitations in accessing the labour market). A foreign national who has been issued with a work permit had to apply for a residence permit for the purpose of employment (if there was no other legal reason for their stay). In times of economic boom (2004-2008) Czech labour offices issued large number of work permits for all jobs, including unskilled ones. In 2008 Ukrainians constituted the vast majority of work permit holders. However, at the very beginning of the economic recession, the Czech state adopted a rather restrictive approach not only toward newcomers but also toward immigrants already in the country. Since the beginning of 2009, the Ministry of Labour and Social Affairs (MoLSA) has sent several memoranda to labour offices aimed at facilitating employment of Czech citizens by strictly regulating the employment of third-country nationals. At first, the Ministry rather vaguely appealed for "greater consideration" of a general decline in the demand for foreign labour within the Czech economy. In spite of a declining trend in direct employment of third-country nationals (including Ukrainians), at the beginning of 2012 the Ministry decided to instruct labour offices to discontinue issuing work permits for positions for which employers do not require Maturita (General Certificate of Secondary Education - GCSE). In June 2012, following strong criticism from NGOs and Czech companies employing immigrants, the Ministry modified these regulations, instructing labour offices to issue and extend work permits for unskilled jobs for a shorter period of time: up to 6 months 
for jobs with no GCSE requirements, up to 1 year for those requiring a GCSE certificate, and up to 2 years for jobs requiring a degree. However, the new memorandum insisted that all applicants provide official proof of their qualifications. To obtain recognition of foreign educational qualifications in the Czech Republic involves a considerable amount of time, knowledge of procedures and paperwork, therefore many migrants may not perceive the advantage of skills recognition and do not expect the procedure to pay off in terms of matching their formal education to a job in the Czech Republic (Leontiyeva and Pokorná 2014).

In November 2013 the Ministry of Labour and Social Affairs modified the regulations again, this time extending the maximum validity of work permits for unskilled and semi-skilled workers to 12 months. The regulations for graduate jobs remained the same, but proof of qualifications was now only required for new work permits, not for the extension of existing ones. In June 2014 the Czech Republic introduced the employee card as a new type of permit for long-term residence where the purpose of stay is employment (see Chap. 7 for a comparison with the single permit introduced in Poland). This card replaced the long-term residence permit (visa) for the purpose of employment and is valid for up to 2 years. The advantage of an employee card lies in its dual nature: it entitles migrants to both reside and work in the territory of the country without needing to apply separately for a residence permit and a work permit in two places. This new card entitles migrants to a limited degree of mobility in the labour market, since both change of employer and multiple jobs are possible, subject to the approval of the ministerial authorities. The employee card is intended for all types of employment, regardless of the level of qualifications required. However, jobs for which foreign employees can apply must be on the central register of vacancies that are specifically designated "suitable for foreigners" and which cannot be taken by native Czech, EU/EEA and Swiss citizens and their family members. ${ }^{3}$

Although the general decline shown in Fig. 8.1 is obvious, statistics for thirdcountry nationals employed since 2012 are missing due to the changes mentioned at the Ministry of Labour and Social Affairs. Available aggregated estimates provided by the Ministry show that by the end of 2014 the number of employed Ukrainian citizens was 35,319 (MoI 2015b), which is almost the same as the number of regular employees with Ukrainian citizenship back in 2011 (35,250 people as shown in Fig. 8.1). However, given the growing number of Ukrainians with permanent residence permits who have free access to the Czech labour market (in 2011 there were 12,798 such employees), it is obvious that the number of employment permits issued to Ukrainian citizens (work permits, employment cards, green cards and blue cards) has fallen significantly since 2011 . The same estimates for 2014 show that the total number of employment permits issued to all third-country nationals was less than 21,000 (MoI 2015b). ${ }^{4}$ This is quite a difference compared with 2011, when the number of work permits issued to third-country nationals was 36,640, of which 22,348 were issued to Ukrainian citizens (CZSO 2015). It is not entirely clear how

\footnotetext{
${ }^{3}$ This register is available on the web site of the MoLSA: http://portal.mpsv.cz/sz/zahr_zam/prociz ${ }^{4}$ Unfortunately these estimates are not available for Ukrainian migrants separately.
} 
effective the measures described above have been in boosting the employment prospects of the domestic workforce. Statistics indicating whether Czech workers subsequently filled positions for which foreigners failed to get permits are not available. As we have seen, the recession did not have such a significant impact on the total number of Ukrainians residing in the country. Given the dynamic of the Czech unemployment rate, it is logical to assume that rather than combating unemployment and exclusion, the measures taken by MoLSA merely influenced the nature of Ukrainian labour migration. It is interesting to compare the situation with that of employed foreign nationals who were not subjected to these rather strict work permit regulations. According to the official numbers, the economic recession did not seem to have such an important impact on the economic activities of Ukrainians (and other third-country nationals) who had free access to the Czech labour market (holders of permanent residence permits, family members, students, etc.), or EU nationals employed in the Czech Republic. On the contrary, these groups exhibited a slight increase in numbers. Thus, the decline in direct employment of Ukrainians cannot be explained purely by staff reductions and the bankruptcy of Czech companies; rather, it seems to be strongly associated with the changing approach to regulation of the labour market (Leontiyeva 2011).

Another important change illustrated in Fig. 8.1 is the $60 \%$ growth in the officially registered entrepreneurial activities of Ukrainian migrants since 2008. In order to understand the dynamics of self-employment among Ukrainians in the Czech Republic, it is important to consider a basic fact behind these official numbers: there are different forms of irregular economic activity carried out by immigrants. In addition to the employment of immigrants without valid residence permits and/or valid work permits, there is the widespread phenomenon of employment hidden behind self-employment. In practice this means hiring the holder of a trade licence (a person who works freelance) without a contract, not only for occasional jobs but also for regular working hours. Although these "bogus employment practices" (in the Czech context often called the "Švarc system") $)^{5}$ are actually illegal under the Czech Labour Code, they are sometimes preferred (mostly for tax reasons) not only by employers and migrants, but also by the native population. This alternative employment strategy may be preferred by immigrants because it seems a more convenient and flexible way to obtain employment avoiding rather rigid foreign labour regulations. A trade licence is relatively easy to obtain in the Czech Republic. ${ }^{6}$ In most cases no proof of qualification is required; and it is possible to change jobs and even to be economically inactive for a while without the threat of losing the official "purpose of stay" status. The relative flexibility of this status in the Czech context (compared with very strict regulations when it comes to the regular employment of foreigners) might seem like a great advantage, especially for

\footnotetext{
${ }^{5}$ This employment practice was nicknamed after the Czech building contractor (M. Švarc), who in the early 1990s fired his employees only to re-hire them again as self-employed to avoid paying social security and health insurance taxes.

${ }^{6}$ Besides, before the crisis it was also relatively easy to obtain a residence permit on the basis of entrepreneurial activities.
} 
unskilled workers such as cleaners, cashiers, welders, construction workers, etc. However, the great disadvantage of this hidden employment is the vulnerability of immigrants who are not protected by the Labour Code and therefore do not enjoy job security, regular pay, adequate working conditions, sick leave, and so on.

There are no reliable data on how widespread the "Švarc system" is among Ukrainian immigrants, although several studies suggest that it may be an important strategy for a considerable share of immigrants, and not only Ukrainians (Drbohlav 2008; Hofírek and Nekorjak 2010; Leontiyeva and Nečasová 2009; Drbohlav, et al. 2010; Čermáková at al. 2011). Estimates on the "Švarc system" (like any irregular economic activities) are of course rather problematic due to the sensitive nature of the subject. However, according to the results of the survey conducted in 2010, just over $5 \%$ of economically active Ukrainians interviewed admitted that they had been employed while holding a trade licence. In the 2013 survey the share of Ukrainians admitting to the bogus employment practices mentioned above was almost $8 \% .^{7}$

\subsection{Typical "Ukrainian Jobs"}

Most economically active Ukrainians work in low-skilled and low-paid jobs in the Czech Republic. As we have seen, strict regulations concerning direct employment have especially targeted low-skilled immigrants working in jobs where secondary education is not a requirement. Figure 8.2 provides an interesting time comparison of the occupational status of Ukrainian employees who held work permits and those who had free access to the labour market. The occupational status of Ukrainians with free access to the labour market was fairly stable between 2004 and 2011. As suggested above, during the same period the employment of Ukrainians regulated by the state experienced striking changes.

According to official statistics, during the economic boom there was rapid growth in elementary (unskilled) occupations, but a significant decline after 2009. It seems that in the wake of the economic crisis the overall occupational status of Ukrainian nationals holding work permits has improved slightly. Later data are not available; however, a significant trend in occupational structure should be expected because of rather strict regulation of the employment of semi-skilled and unskilled migrants described above. At the end of 2011, 52\% of employed Ukrainians occupied elementary jobs (ISCO 9); while $41 \%$ of them occupied semi-skilled jobs (ISCO 4-8), most often as craft and related trade workers (ISCO 7; 20\%). During the same period only $7 \%$ of employed Ukrainians succeeded in securing managerial, professional or other skilled job (ISCO 1-3). When it comes to economic sectors, Ukrainians were mostly employed in construction (44\%), manufacturing

\footnotetext{
${ }^{7}$ Numbers are based on the author's analysis of primary data from the surveys mentioned. The quality and comparability of the quota samples described (including the comparison with available statistical data) are discussed in the methodological article by Bernard and Leontiyeva (2013).
} 


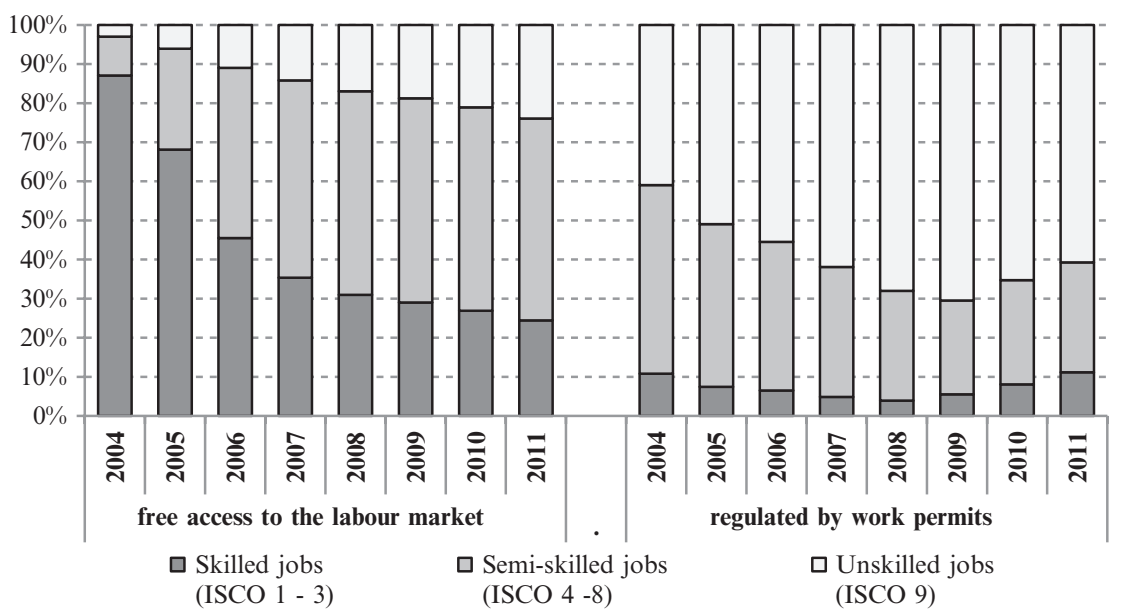

International Standard Classification of Occupations (Major groups of ISCO) merged into three groups according to skills requirement:

\section{Skilled jobs}

1. Legislators, senior officials, and managers

2. Professionals

3. Technicians and associate professionals

Semi-skilled jobs

4. Clerks

5. Service and sales/shop/market workers

6. Skilled agricultural and fishery workers

7. Craft and related trade workers

8. Plant and machine operators and assemblers

\section{Unskilled jobs}

9. Elementary occupations

Fig. 8.2 Occupational structure of Ukrainian nationals with employee status (Source: CZSO 2015)

$(21 \%)$, wholesale and retail trade, repair of motor vehicles, personal and household goods (8\%), and transport, storage and communications (6\%) (CZSO 2015).

Unfortunately, there are no detailed data on the occupational structure of selfemployed Ukrainians. The lack of official statistics is at least partly compensated by the surveys of economically active Ukrainian migrants conducted in 2010 and 2013 cited above. The 2010 data suggest that the employment status of migrants affects their chance of having a skilled job (ISCO 1-3). Regardless of age, education, origin, etc., self-employed migrants were much more likely to be in skilled jobs (as opposed to semi-skilled) than waged, employed migrants. At the same time, this 
survey suggests that self-employed and waged Ukrainian employees have an equal propensity toward being employed in unskilled jobs (ISCO 9) (Leontiyeva 2014a). Data gathered in 2013, however, produced slightly different findings, suggesting that self-employment might improve the position of Ukrainian migrants on the labour market - it improves the odds of being employed not only in skilled jobs but also in semi-skilled (ISCO 4-8) as compared with unskilled jobs (ISCO 9) (Bernard and Leontiyeva 2013).

Although quantitative data available suggest that domestic work is still not very widespread among the largest group of immigrants - which is still rather dominated by men - it has become more relevant over the last decade. The involvement of migrants in care and domestic work is attracting growing attention among Czech researchers, especially with regard to the rights of female immigrants engaged in domestic work - primarily cleaning and less frequently care. A report by Ezzeddine et al. (2014) suggests that there is an increasing demand for domestic services in the Czech Republic. Exploratory research based on interviews with 105 migrant women (60\% of them from Ukraine) employed in the domestic sector revealed that, unlike Filipino women, most Ukrainian domestic workers do not live at the employer's house and often have several jobs. According to this study a significant proportion of Ukrainian women working in the domestic sector are over-qualified and often come from transnational families. Since these women often leave their children back in Ukraine, they have little choice but to accept precarious work in order to be able to support their family (Ezzeddine et al. 2014). An interesting example is the campaign "Do you know who cleans your place?" initiated by a Czech NGO and aimed not only at supporting the rights of domestic workers but also at raising awareness of the phenomenon among the native population. ${ }^{8}$ The advertisement featured a Ukrainian teacher working as a cleaning lady, treated without respect by her employer.

\subsection{Just a Low-Skilled Labour Force - or Well-Educated but Over-Qualified Workers?}

Ukrainians in the Czech Republic are portrayed as well-educated but over-qualified and underpaid (Drbohlav et al. 2001; Uherek and Plochová 2003; Drbohlav and Dzúrová 2007; Drbohlav et al. 2010; Ezzeddine 2012). However, recent data and available statistics might suggest a different picture. According to internal statistics from MoLSA, at the end of 2011 the educational level of employed Ukrainian citizens was in fact low, as the majority of work permit holders only had elementary education (see Table 8.1).

These detailed data gathered by the Czech labour offices until 2011 are available on demand. The data include detailed information about third-country nationals

\footnotetext{
${ }^{8}$ The link to this social advertisement is available on the website of the project: http://www. migrace.com/en/support/media/video/6_vite-kdo-vam-doma-uklizi
} 
Table 8.1 Educational level of Ukrainian citizens employed in the Czech Republic in 2011

\begin{tabular}{l|l|l|l|l|l}
\hline & \multirow{4}{|l|}{$\%$} & \multicolumn{3}{l}{} \\
\cline { 4 - 7 } & \multirow{2}{*}{$\begin{array}{l}\text { Absolute } \\
\text { numbers }\end{array}$} & $\begin{array}{l}\text { Elementary } \\
\text { education and less }\end{array}$ & $\begin{array}{l}\text { Secondary } \\
\text { education }\end{array}$ & $\begin{array}{l}\text { Tertiary } \\
\text { education }\end{array}$ & N/A \\
\hline Work permit holders & 31,407 & 61.8 & 35.8 & 2.1 & 0.3 \\
\hline $\begin{array}{l}\text { Others employed } \\
\text { without work permit }\end{array}$ & 10,696 & 33.2 & 52.7 & 11.4 & 2.7 \\
\hline
\end{tabular}

Source: MoLSA internal statistics valid for 31 December2011

with free access to the labour market as well as work permit holders. The educational level achieved and required were reported by the employee during a work permit application process or reported by the employer based on the regulations concerning the employment of third-country nationals (those with free access to the labour market). In most cases labour offices did not require proof of the migrant's qualifications (diploma or certificate), i.e. the data was based on their declaration or self-reporting. Despite these shortcomings, it is logical to expect these unique data to show relatively high validity. This is due to the fact that the results of this reporting had a direct impact on the migrant's official status and his or her employment (especially for work permit holders).

According to available sample surveys, the share of university graduates among directly employed Ukrainians varies between $10 \%$ and $13 \%$, while around five or six in ten of Ukrainian employees have not completed secondary education (Horáková and Čerňanská 2001; Leontiyeva and Nečasová 2009; Leontiyeva and Tollarová 2011; Bernard and Leontiyeva 2013). The share of university graduates among self-employed Ukrainians is slightly higher but still comparable (Leontiyeva and Tollarová 2011). The results of these surveys do not seem to support rather popular stereotypes of the average Ukrainian as a university-educated construction worker or cleaner.

Labour market incorporation is generally considered a precondition for the successful integration of migrants into the host society. In turn, matching the education and skills of migrants to jobs in the destination country is often used as an indicator of labour market integration (Eurostat 2010; OECD 2014). A large proportion of Ukrainian migrants have lower than secondary education but what about those who have higher educational achievements? Survey data suggest that most of those with extended schooling tend to have skilled jobs (Leontiyeva and Tollarová 2011; Leontiyeva 2014). Nevertheless, a comparison of the educational and occupational status of migrants provides evidence of a significant waste of human capital, and suggests that well-educated Ukrainian immigrants are not always successful on the labour market. The risk of over-education among Ukrainians is relatively high; every fifth Ukrainian employed occupies a position in which most other employees have significantly lower educational achievements. The finding that post-migration experience (i.e. a longer stay in the Czech Republic) might not help Ukrainian immigrants to "catch up" in terms of matching their higher educational attainment to more appropriate occupations, especially when the starting point is at the bottom of the labour market, is also alarming. Institutional obstacles to labour mobility 
through work permit regulation may lower the expectations of immigrants and slow their integration into the Czech Republic. The reality that Ukrainians more often than, for example, Russian or even Vietnamese migrants occupy unskilled jobs cannot be explained by the individual characteristics of these immigrants, or their less stable legal status and lower educational level. Detailed analysis of the data from surveys conducted in 2006 and 2010 showed that having Ukrainian citizenship increases the migrant's risk of being over-educated and occupying the least prestigious jobs compared with other frequently found nationalities with the same characteristics (Leontiyeva 2014).

\subsection{Temporary Labour Migrants or Future Largest National Minority?}

There is no straightforward answer to whether Ukrainian immigrants want to settle down in the Czech Republic, bring their families, and limit contact with the destination country to a minimum. However, there are certain developments that have become rather obvious within the last decade. The share of permanent residence permit holders among Ukrainian immigrants has grown significantly, especially following the economic recession, when the Czech state limited the number of new long-term visas and work permits for Ukrainians.

Almost seven thousand Ukrainian nationals (6, 656 people) received Czech citizenship between 1993 and 2013 (CZSO 2015). Previous studies suggest that many Ukrainians did not apply for Czech citizenship because they did not want to lose their Ukrainian nationality (Leontiyeva and Nečasová 2009). The Czech Republic's new citizenship law (Act No. 186/2013 Coll.), which came into force on 1 January 2014, introduces dual citizenship. Although Ukrainian law does not allow dual citizenship, the number of applications is expected to increase. According to an MoI report the number of Ukrainian citizens naturalized in 2014 was 2077, which was more than double the annual maximum in previous years (MoI 2015b). ${ }^{9}$

Certain features of Ukrainian immigration support the notion of transnational spaces: the geographical proximity of Ukraine; a high degree of separation from the nuclear family; intensive contact with the country of origin; and frequent visits back home, etc. (Drbohlav and Dzúrová 2007; Leontiyeva and Nečasová 2009). Given the relatively high degree of separation from their closest family members it is not surprising that a significant proportion of Ukrainian migrants financially support someone back home. A case study by Strielkowski et al. (2012) conducted in the region of Transcarpathian Ukraine suggests that the typical Ukrainian breadwinner

\footnotetext{
${ }^{9}$ According to internal statistics from the authorized centres for compulsory exams required for citizenship application, Ukrainians also represent the vast majority of applicants in the first half of 2015.
} 
is a middle-aged man from a fairly poor family, irrespective of education. ${ }^{10}$ According to a 2010 survey, approximately six in ten economically active Ukrainian immigrants, irrespective of gender, sent financial remittances to support family and close relatives between 2008 and 2010. This survey suggests that (under similar circumstances) both Ukrainian women and men face similar obligations to support their family back home, but men tend to transfer larger sums than women (Leontiyeva and Tollarová 2011; Leontiyeva 2015).

There is limited data on whether Ukrainian immigrants want to prolong their stay in the Czech Republic. The results of a 2006 survey revealed that 36\% of Ukrainian work permit holders wished to stay in the country for at least five more years, while more than one-third of them were undecided about their future. Similarly, $43 \%$ did express a wish to apply for permanent residency, a status that in many respects affords them the same rights as Czech citizens, while about one-third did not express specific plans to change their residence status (Leontiyeva 2010). A later survey, conducted in 2013, showed that Ukrainian migrants expressed an even stronger tendency to plan a long-term stay in the Czech Republic: the share of economically active Ukrainian respondents who would like to stay in the country for the next 5 years was over $80 \%$. Besides, migrants who remained in the country already had their families with them and appeared to be more integrated in terms of contact with the Czech population than the Vietnamese immigrants (Bernard and Mikešová 2014).

\subsection{Conclusions}

Ukrainians are the largest group among migrants in the Czech Republic. Due to geographical, cultural and historical closeness and because of the significant growth of the Czech economy and the rather liberal migration policies of the Czech state towards unskilled immigrants before the economic recession, this country offered many Ukrainian migrants not only a chance to enhance their financial status and feed their families back in Ukraine but also an opportunity to build strong ethnic networks and find a relatively comfortable new home in the European Union. In fact, in the region of Central and Eastern Europe the Czech Republic is one of the most attractive destinations when it comes to contemporary Ukrainian migration; the number of officially registered Ukrainian citizens in the Czech Republic is higher than, for example, in Poland and almost as high as in Germany (see Chaps. 1 and 7). Ukrainian migration to this country is an interesting example of transformation from the temporary foreign labour force (with rather low aspiration to settlement and very widespread transnational practices including back-and-forth migration) to one of the largest groups of settled immigrants (who put down roots in

\footnotetext{
${ }^{10}$ This exploratory study focused on immigrants in the region sending remittances and their families left back home. The results are however far from representative and could hardly be generalized to the total population of Ukrainians living in the Czech Republic.
} 
the country of destination, became settled or even naturalized and started bringing in family members). The global economic recession adversely affected Czech economic performance and had a significant impact on the country's attitude towards foreign labour. Although Ukraine's migration potential is still significant, the inflow of Ukrainians to the Czech Republic practically stopped after 2008 due to rigid policies and practices. Although the absolute number of Ukrainian migrants officially registered in the country dropped slightly, there was no massive return of migrants.

Nowadays Ukrainians in the Czech Republic represent a very diverse group of migrants. They can be found on construction sites, in supermarkets and in cleaning services, at Czech schools and universities, in managerial positions in big companies, among owners of small businesses, and even among the winners of prizes for the best young scientists. Many of them are integrated into Czech society, especially when it comes to the second generation of immigrants. Although a considerable proportion of Ukrainians rely on ethnic networks to look for jobs and many of them occupy jobs very typical for migrants, they do not form ethnic enclaves and are not very concentrated spatially (Leontiyeva and Nečasová 2009; Valenta 2012; Bernard and Mikešová 2014).

More in-depth research is needed to answer many outstanding questions.

- How has the economic recession influenced the migration patterns of Ukrainians?

- Will the new state regulations have an impact on transnational practices of Ukrainian nationals and their preferences toward settlement in the Czech Republic?

- Will a potential increase in the spatial concentration of Ukrainians result in ghettoization in the future?

- What is the role of ethnic economies and family migration on the integration of Ukrainian immigrants?

- What is the integration potential of the second generation of Ukrainian immigrants in the Czech Republic?

\section{References}

Bernard, J., \& Leontiyeva, Y. (2013). Cizinci jako obtížně dosažitelná populace. [Foreigners as a hard-to-reach popupation]. Data a výzkum - SDA Info, 7(1), 57-82. doi: http://dx.doi. org/10.13060/1802-8152.2013.7.1.3.

Bernard, J., \& Mikešová, R. (2014). Sociální integrace imigrantů na rozhraní mezi dočasnou migrací a trvalým usazením. [The Socio-cultural integration of immigrants: In Between temporary migration and permanent settlement]. Sociologický časopis/Czech Sociological Review, 50(4), 521-546. doi: http://dx.doi.org/10.13060/00380288.2014.50.4.107.

Čermáková, D., \& Nekorjak, M. (2009). Ukrainian middleman system of labour organisation in the Czech Republic. Journal of Economic \& Social Geography, 100(1), 33-43.

Čermáková, D., Schovánková, S., \& Fiedlerová, K. (2011). Podnikání cizinců v Česku: vliv struktury příležitostí. [Entrepreneurial activities of foreigners in the Czech Republic: The influence of the structure of the opportunities]. Geografie, 4(4), 440-461.

Czech Statistical Office (CZSO). (2015). Foreigners in the Czech Republic 2014. https://www. czso.cz/csu/czso/foreigners-in-the-czech-republic-2014-x9xhb72sby. Accessed 1 Aug 2015. 
Drbohlav, D., \& Dzúrová, D. (2007). Where are they going?: Immigrant inclusion in the Czech Republic (A case study on Ukrainians, Vietnamese, and Armenians in Prague). International Migration, 45(2), 69-95.

Drbohlav, D., \& Lachmanová, L. (2008). Irregular activities of migrants in the Czech Republic: A delphi study about adaptations in a globalising economy. In P. Dostál (Ed.), Evolution of geographical systems and risk processes in the global context (pp. 129-156). Prague: Charles University in Prague, Faculty of Science.

Drbohlav, D., Janská, E., \& Šelepová, P. (2001). Ukrajinská komunita v České republice. [Ukrainian community in the Czech Republic.]. In T. Šišková (Ed.), Menšiny a migranti v České republice: My a oni v multikulturníspolečnosti 21. století (pp. 89-97). Praha: Portál.

Drbohlav, D., Medová, L., Čermák, Z., Janská, E., Čermáková, D., \& Dzúrová, D. (2010). Migrace a (i)migranti v Česku. Kdo jsme, odkud přicházíme, kam jdeme? [Migration and (i)migrants in the Czech Republic. Who we are, where do we come from, where are we going?]. Praha: Slon.

Eurostat. (2010). Demography report. Commission staff working Document. European Commission: Eurostat. ec.europa.eu/social/BlobServlet?docId=6824\&langId=en. Accessed 01 Aug 2015.

Ezzeddine, P. (2012). Mateřství na dálku. Transnacionální mateřství ukrajinských migrantek v České republice. [Long distance motherhood. Transnational motherhood of Ukrainian migrants in the Czech Republic]. Gender, rovné príležitosti, 13(1), 24-32.

Ezzeddine, P. et al. (2014). Migrantky a nájemná práce v domácnosti v České republice. [Female migrants and domestic work in the Czech Republic.] Praha: Sdružení pro integraci a migraci. http://www.migrace.com/docs/140925_vysledky-vyzkumu-najemne-prace-v-domacnosti-vcr.pdf. Accessed 1 Aug 2015.

Ezzeddine-Lukšíková, P., Kocourek, J., \& Leontiyeva, Y. (2006). Internal restrictions on the participation of the Vietnamese and Ukrainian ethnic groups on the Czech labour market. Prague: International Organization for Migration. https://www.cerge-ei.cz/pdf/gdn/rrc/RRCV_53_ paper_01.pdf. Accessed 1 Aug 2015.

Hofírek, O., \& Nekorjak, M. (2010). Od pásu ke stánku - a zpět? Proměny ekonomických aktivit Vietnamců v České republice. [From the production line to the market stand and back? Transformation of economic activities of the Vietnamese in the Czech Republic.]. In R. Trbola \& M. Rákoczyová (Eds.), Vybrané aspekty života cizincư v České republice (pp. 77-94). Praha: Výzkumný ústav práce a sociálních věcí.

Horáková, M., \& Čerňanská, D. (2001). Zaměstnávání cizincư v České republice. Část II. Závěrečná zpráva z empirického šetření. [Employment of foreigners in the Czech Republic. Part II. Final report from an empirical investigation.] Praha: Výzkumný ústav práce a sociálních věcí. http:// praha.vupsv.cz/Fulltext/zamci2.pdf. Accessed 1 Aug 2015.

Horáková, M., \& Drbohlav, D. (1998). Mezinárodní migrace pracovních sil a Česká republika se zvláštním zaměřením na pracovní migraci Ukrajinců. [International migration of labour force and the Czech Republic with a special emphasis on labour migration of Ukrainians]. Demografie, 40(1), 27-38.

Janská, E., \& Drbohlav, D. (2001). Reemigrace volyňských a ‘černobylských' Čechů [Re-emigration of Czechs from the Volyn and Chernobyl]. In T. Šišková (Ed.), Menšiny a migranti v České republice (pp. 107-115). Praha: Portál.

Leontiyeva, Y. (2005). Minority organizations as possible mediators for civic participation of migrants. The example of Ukrainians in Czech Republic. In H. Rusu \& B. Voicu (Eds.), Perspectives on the European postcommunist societies (pp. 47-56). Sibiu: Psihomedia.

Leontiyeva, Y. (2010). Good for one and all! Does the Czech economy make efficient use of nonEU labour migrants? Socioweb, 7-8/2010, 17-21. http://www.socioweb.cz/upl/editorial/download/181_pdf\%202010\%2007\%2008.pdf. Accessed 1 Aug 2015.

Leontiyeva, Y. (2011). Imigranti v ČR - žádaní a nechtění. Současné migrační a integrační politiky v C R. [Immigrants in the Czech Republic - demanded and unwanted. Current migration and integration policies in the Czech Republic]. In M. Rákoczyová \& R. Trbola (Eds.), Institucionální podmínky sociální integrace cizincư v $\check{C} R I$ (pp. 13-36). Brno: Barrister \& Principal. 
Leontiyeva, Y. (2014). The education-employment mismatch among Ukrainian migrants in the Czech Republic. Central and Eastern European Migration Review, 3(1), 63-84.

Leontiyeva, Y. (2015). Kdo jsou ukrajinští migranti, kteří posílají peníze do zahraničí? Analýza faktorů ovlivňujících posílání peněžních remitencí [Who are those Ukrainian immigrants sending money abroad? The analysis of factors influencing the remittance behaviour]. In D. Drbohlav (Ed.), Ukrajinská pracovní migrace v Česku: migrace - remitence - (rozvoj) (pp. 185-200). Praha: Univerzita Karlova v Praze, Nakladatelství Karolinum.

Leontiyeva, Y., \& Nečasová, M. (2009). Kulturně blízcí? Integrace přistěhovalců ze zemí bývalého Sovětského svazu. [Culturally close? Integration of immigrants from the Ex-Soviet Union countries.]. In M. Rákoczyová \& R. Trbola (Eds.), Sociální integrace pristěhovalců v České republice (pp. 117-160). Praha: Sociologické nakladatelství.

Leontiyeva, Y., \& Pokorná, A. (2014). Faktory bránící využití kvalifikace imigrantů na trhu práce $v \check{C} R$. Vyzzumná zpráva. [Factors hindering the use of immigrants' skills on the Czech labour market. Research report] Praha: Multikultirní centrum. http://www.mkc.cz/data/kvalifikacefinal.pdf. Accessed 1 Aug 2015.

Leontiyeva, Y., \& Tollarová, B. (2011). Results from a survey of foreigners' incomes, expenditures and remittances. Main findings concerning remittances. Prague: Institute of Sociology. http:// www.soc.cas.cz/sites/default/files/soubory/immigrants_2010_-_report.pdf. Accessed 1 Aug 2015.

Lupták, M., \& Drbohlav, D. (1999). Labour migration and democratic institutions in the Czech Republic (on the Example of Ukrainian Workers). Research report for NATO under Democratic Institutions individual fellowship program1995/1997. Prague. http://www.nato.int/acad/fellow/97-99/luptak.pdf. Accessed 1 Aug 2015.

Markus, V. (1994). Ukrainians in the Czech and Slovak Republic. In A. L. Pawliczko (Ed.), Ukraine and Ukrainians throughout the world: The demographic and sociological guide to the homeland and its Diaspora (pp. 147-156). Toronto: University of Toronto Press.

Ministry of the Interior (MoI). (2015a). Cizinci s povoleným pobytem. [Foreigners with valid residence permit]. http://www.mvcr.cz/clanek/cizinci-s-povolenym-pobytem.aspx. Accessed 1 Feb 2016.

Ministry of the Interior (MoI). (2015b). Zpráva o situaci v oblasti migrace a integrace cizinců na území České republiky v roce 2014. [Report on the situation in the area of migration and integration of foreigners on the territory of the Czech Republic in 2014]. http://www.mvcr.cz/ clanek/zprava-o-situaci-v-oblasti-migrace-a-integrace-cizincu-na-uzemi-ceske-republiky-vroce-2014.aspx. Accessed 1 Aug 2015.

Nekorjak, M. (2006). Klientský systém a ukrajinská pracovní migrace do České Republiky. [Client system and Ukrainian labour migration to the Czech Republic]. Sociální studia, 1/2006, 89-109.

Nekorjak, M. (2007). Úvahy nad neregulérní migrací se zaměrením na ukrajinskou migraci v Česku. [Some reflections on irregular migration with a focus on Ukrainian migration to the Czech Republic]. IVRIS Working Papers. Brno: Institut pro výzkum integrace a reprodukce společnosti.

Nosková, H. (1999). Návrat Čechů z Volyně. Naděje a skutečnost let 1945-1954. [The return of Czechs from the Volyn region. Hope and reality]. Praha: Ústav pro soudobé dějiny AV ČR.

OECD. (2014). International migration outlook 2014. Special focus: Mobilising migrants' skills for economic success. OECD Publishing. http://dx.doi.org/10.1787/migr_outlook-2014-en. Accessed 1 Aug 2015.

Strielkowski, W., Glazar, O., \& Weyskrabová, B. (2012). Migration and remittances in the CEECs: A case study of Ukrainian labour migrants in the Czech Republic. Prague: IES Working Paper 19/2012, Charles University.

Trlifajová, L. (2009). Proměny současné ukrajinské imigrace. Role a formy identity v kontextu vývoje ukrajinské migrace do Česka. Diplomová práce. [The change in Ukrainian immigration. The role of identity and its different forms in the context of transformation of Ukrainian migration to the Czech Republic. Master's Diploma Thesis] Praha: Univerzita Karlova v Praze, Filozofická fakulta. 
Uherek, Z., \& Plochová, K. (2003). Migration from the former Soviet Union to the Czech Republic: Comparing the cases of resettlers from areas affected by the Chernobyl nuclear disaster, Kazakhstan and labour migration from subcarpathian Ukraine. In D. Torsello \& M. Pappová (Eds.), Social networks in movement: Time, interaction and interethnic spaces in central eastern Europe (pp. 211-227). Šamorín/Dunajská Streda: Forum Minority Research Institute.

Uherek, Z., Valášková, N., Bělohradská, K., \& Mušinka, M. (2008). Pracovní migrace ze Zakarpatské Ukrajiny do České republiky. [Labour migration for the sub-carpathian Ukraine to the Czech Republic]. In Z. Uherek, Z. Korecká, T. Pojarová, et al. (Eds.), Cizinecké komunity z antropologické perspektivy: vybrané př́pady významných imigračních skupin v České republice (pp. 121-148). Praha: Etnologický ústav AV ČR.

Valášková, N., Uherek, Z., \& Brouček, S. (1997). Aliens or one's own people. Czech immigrants from the Ukraine in the Czech Republic. Praha: Etnologický ústav AV ČR.

Valenta, O. (2012). Cizinci v Praze: prostorová koncentrace Slováků, Ukrajinců a Vietnamců. [Foreigners in Prague: The spatial concentration of Slovaks, Ukrainians and Vietnamese]. In M. Ouředníček \& J. Temelová (Eds.), Sociální proměny pražských čtvrtí (pp. 92-115). Praha: Academia.

Zilynskyj, B. (1995). Ukrajinci v Čechách a na Moravě (1894) 1917 - (1945) 1994. [Ukrainians in Czech and Moravian lands (1894) 1917 - (1945) 1994]. Praha: X-Egem.

Zilynskyj, B. (2000). Ukrajinci v českých zemích v letech 1945-1948. [Ukrainians in Czech lands during 1945-1948]. Praha: Ústav pro soudobé dějiny Akademie věd ČR.

Zilynskyj, B. (2002). Ukrajinci v českých zemích po roce 1989. [Ukrainians in Czech lands after 1989]. Praha: Ústav pro soudobé dějiny AV ČR.

Zilynskyj, B., \& Kočík, R. (2001). Ukrajinci v ČR. [Ukrainians in the Czech Republic]. In T. Šišková (Ed.), Menšiny a migranti v České republice: My a oni v multikulturní společnosti 21. století (pp. 81-88). Praha: Portál.

Open Access This chapter is distributed under the terms of the Creative Commons AttributionNoncommercial 2.5 License (http://creativecommons.org/licenses/by-nc/2.5/) which permits any noncommercial use, distribution, and reproduction in any medium, provided the original author(s) and source are credited.

The images or other third party material in this chapter are included in the work's Creative Commons license, unless indicated otherwise in the credit line; if such material is not included in the work's Creative Commons license and the respective action is not permitted by statutory regulation, users will need to obtain permission from the license holder to duplicate, adapt or reproduce the material. 